\title{
Applications of Virtual Reality Technology in the Measurement of Spatial Memory in Patients with Mood Disorders
}

To the Editor:

March 28, 2006

The January 2006 CNS Spectrums included an article about virtual reality (VR) technology as a treatment option in psychiatry and Dr. Gorman ${ }^{1}$ welcomed letters discussing novel applications of VR in psychiatry. Much of the published work in this area is treatment-related. It appears that a limited number of researchers have considered using this technology for clinical assessment and research purposes. This is likely to change as immersive VR shows promise for increasing ecological validity in assessment and providing a much richer set of behavioural data.

In collaboration with the Informatics Research Institute (IRI) at Newcastle University in Newcastle upon Tyne, England, we are assessing the validity of this approach. The IRI manages an immersive VR suite, and our collaboration has allowed us to develop a novel paradigm to test spatial memory in patients with mood disorders. Our interest in spatial memory in this group stems from neuroimaging research reporting atrophy in the hippocampal region for patients with major depressive disorder ${ }^{2,3}$ and bipolar disorder. ${ }^{4}$ The hippocampus is involved in spatial memory, ${ }^{5}$ and individuals with hippocampal lesions are impaired on tasks of spatial memory. ${ }^{6}$

Spatial memory deficits have been reported in some, but not all, patients with mood disorders. ${ }^{7-}$ ${ }^{13}$ The inconsistency is perhaps a reflection of the variety of methodologies used to assess spatial memory. It has also been speculated that this is due to the nature of the tasks used to measure spatial ability. Many tests involve memorizing the locations of objects in two-dimensional space. Such tasks have been criticized for lacking ecological validity since the skills they assess are not often used in everyday life. At the present time, self-report questionnaires measuring sense of direction are likely the measures most highly correlated with everyday environmental spatial ability. ${ }^{14}$ However, this type of assessment does not provide detailed information about spatial processes and we are in need of better methods for assessing spatial ability. ${ }^{14}$

More recently, spatial memory research has turned to desktop-based VR tasks to assess memory of locations in and speed and accuracy of navigation through a maze, pool of water, or town. ${ }^{15-20}$ Immersive VR technology, as opposed to desktopbased VR, permits superior perceptual experience and experimental control by offering high-quality stereo graphics in a fully tracked virtual environment. These attributes make immersive VR technology a powerful and potentially ecologically valid technique that shows promise for improving assessment methods of spatial memory and providing insight into previously reported spatial memory deficits in patients with mood disorders.

Our research paradigm involves the use of a life-like and complex immersive VR town that participants will navigate using a wireless joystick. During the first phase of the experiment, participants will learn and replicate various routes through the town. In the second phase, they will use their knowledge of the layout of the town to navigate between localities that they have not previously navigated between. This will assess their ability to form an accurate mental representation of the environment. For example, a participant might begin at the Post Office and be asked to navigate to the Library. We will assess the speed and accuracy of their 
navigation and their ability to use various spatial strategies to find locations within the town.

For a more detailed exploration of the roles that stereo display, large field of view, head tracking, and three-dimensional spatial interaction devices play in the spatial memory process, we have also created an immersive VR version of a widely used two-dimensional spatial memory task. Participants will perform this task in three different conditions (in random order): on a desktop computer; in the immersive VR suite without stereo cues; and in the immersive VR suite with stereo cues. We predict that participants will perform differently depending on the level of immersion. We will also evaluate whether different amounts of immersion more effectively discriminate patients from healthy controls.

We are optimistic that this research will not only provide more detailed information about spatial memory in mood disorders but that it will also encourage other researchers to develop paradigms using immersive VR technology in the future. When the equipment is available, immersive VR can provide a controlled, life-like environment to assess behaviour in a variety of experimental contexts.

Sincerely,

M. Kathleen Holmes, BS,

Peter Gallagher, BSc (Hons), MPhil

Lucy J. Robinson, BA (Hons), BSc (Hons),

John M. Gray, MA (Hons), PhD, MPhil(CPsychol),

Patrick Olivier, MA, Dip, MSc, PhD,

Philip Heslop, MSc, and

I. Nicol Ferrier, BSc (Hons), MD, FRCP, FRCPsych, Newcastle upon Tyne, England

\section{REFERENCES}

1. Gorman JM. Virtual reality: a real treatment option. CNS Spectr. 2006:11:12-13

2. Sheline YI, Wang PW, Gado MH, Csernansky JG, Vannier MW. Hippocampal atrophy in recurrent major depression. Proc Natl Acad Sci US A. 1996;93:3908-3913

3. Hickie I, Naismith S, Ward PB, et al. Reduced hippocampal volumes and memory loss in patients with early- and late-onset depression. Br J Psychiatry. 2005;186:197-202.

4. Blumberg HP, Kaufman J, Martin A, et al. Amygdala and hippocampal volumes in adolescents and adults with bipolar disorder. Arch Gen Psychiatry. 2003;60:1201-1208.

5. Zola SM, Squire LR. The medial temporal lobe and the hippocampus. In: Tulving $E$, Craik FIM, eds. The Oxford Handbook of Memory. New York, NY: Oxford University Press: 2000:485-500.

6. Kessels RP, de Haan EH, Kappelle LJ. Postma A. Varieties of human spatial memory: a meta-analysis on the effects of hippocampal lesions. Brain Res Brain Res Rev. 2001:35:295-303.

7. Sweeney JA, Kmiec JA, Kupfer DJ. Neuropsychologic impairments in bipolar and unipolar mood disorders on the CANTAB neurocognitive battery. Biol Psychiatry. 2000;48:674-684.
8. Weiland-Fiedler P, Erickson $K$, Waldeck $T$, et al. Evidence for continuing neuropsy chological impairments in depression. J Affect Disord. 2004;82:253-258

9. Rubinsztein JS, Michael A. Paykel ES, Sahakian BJ. Cognitive impairment in remission in bipolar affective disorder. Psychol Med. 2000;30:1025-1036.

10. Porter RJ, Gallagher P. Thompson JM, Young AH. Neurocognitive impairment in drugfree patients with major depressive disorder. Br J Psychiatry. 2003;182:214-220

11. Murphy FC, Sahakian BJ, Rubinsztein JS, et al. Emotional bias and inhibitory control processes in mania and depression. Psychol Med. 1999;29:1307-1321.

12. Hill SK, Keshavan MS, Thase ME, Sweeney JA. Neuropsychological dysfunction in antipsychotic-naive first-episode unipolar psychotic depression. Am J Psychiatry. 2004; 161:996-1003.

13. Larson ER, Shear PK, Krikorian R, Welge J, Strakowski SM. Working memory and inhibitory control among manic and euthymic patients with bipolar disorder. $J$ Int Neuropsychol Soc. 2005:11:163-172.

14. Waller D. The WALKABOUT: Using virtual environments to assess large-scale spatial abilities. Comput Human Behav. 2005;21:243-253.

15. Astur RS, Taylor LB, Mamelak AN, Philpott L, Sutherland RJ. Humans with hippocampus damage display severe spatial memory impairments in a virtual Morris water task. Behav Brain Res. 2002;132:77-84.

16. Driscoll I, Hamilton DA, Yeo RA, Brooks WM, Sutherland RJ. Virtual navigation in humans: the impact of age, sex, and hormones on place learning. Horm Behav. 2005; 47:326-335.

17. Hartley T, Maguire EA, Spiers HJ, Burgess N. The well-worn route and the path less traveled: distinct neural bases of route following and wayfinding in humans. Neuron. 2003;37:877-888.

18. Maguire EA, Burgess N, Donnett JG, et al. Knowing where and getting there: a human navigation network. Science. 1998;280:921-924.

19. Pine DS, Grun J, Maguire EA, et al. Neurodevelopmental aspects of spatial navigation: a virtual reality fMRI study. Neuroimage. 2002;15:396-406.

20. Shore DI, Stanford L, Maclnnes WJ, Klein RM, Brown RE. Of mice and men: virtual Hebb-Williams mazes permit comparison of spatial learning across species. Cogn. Affect Behav Neurosci. 2001:1:83-89

Miss Holmes is assistant psychologist; Mr. Gallagher is research associate; Miss Robinson is a PhD student; Dr. Gray is a clinical neuropsychologist; and Prof. Ferrier is head of school, School of Neurology, Neurobiology, and Psychiatry, all at the School of Neurology, Neurobiology and Psychiatry, Newcastle University, Newcastle upon Tyne, England. Dr. Olivier is senior lecturer and Mr. Heslop is a virtual reality support officer both at the Informatics Research Institute at Newcastle University in Newcastle upon Tyne, England.

Disclosures: Dr. Gray is currently receiving partial research support from a Medical Research Council grant; and has previously recevied research support from the Chief Scientist's Office, the Scottish Office, and the Newcastle Mental Health National Health Service Trust. Dr. Olivier receives research support from the Engineering and Physical Sciences Research Council, the Department of Trade and Industry, and Unilever. Prof. Ferrier has received fees for speaking engagements from AstraZeneca, Bristol-Myers Squibb, Eli Lilly, Janssen-Cilag, Lundbeck, Organon, and Wyeth; has been on the advisory boards for Eli Lilly, JanssenCilag, Novartis, Organon, and Wyeth; and has received educational grants for research from Eli Lilly, Janssen-Cilag, Organon, and Wyeth. Ms. Holmes, Mr. Gallagher, Miss Robinson, and Mr. Heslop report no affiliation with or financial interest in any organization that may pose a conflict of interest.

Please send letters to the editor to: CNS Spectrums, c/o Jack M. Gorman, MD, 333 Hudson St., 7th Floor, New York, NY 10013; E-mail: VJ@mblcommunications.com. 